Marquette University

e-Publications@Marquette

Social and Cultural Sciences Faculty Research and

Publications

Social and Cultural Sciences, Department of

$1-1-2012$

\title{
Redemption from the Inside-Out: The Power of Faith-Based Programming
}

Barbara H. Zaitzow

Appalachian State University

Richard S. Jones

Marquette University, richard.jones@marquette.edu

Accepted version. "Redemption from the Inside Out: The Power of Faith-Based Programming," in Special Needs Offenders in Correctional Institutions. Ed. Lior Gideon. Thousand Oaks: SAGE Publications, 2012: 319-344. Permalink. (C) 2012 SAGE Publications. Used with permission. 


\title{
Redemption from the Inside-Out: The Power of Faith-Based Programming
}

\author{
Barbara H. Zaitzow \\ Department of Government and Justice Studies \\ Appalachian State University \\ Boone, NC \\ Richard S. Jones \\ Department of Social and Cultural Sciences \\ Marquette University \\ Milwaukee, WI
}

\begin{abstract}
Prisons are tense, cheerless, and often degrading places in which all inmates struggle to maintain their equilibrium despite violence, exploitation, lack of privacy, stringent limitations on family and community contacts, and a paucity of opportunities for meaningful education, work, or other productive activities. As a general matter, prisoners come to see prison as their home and try to make the most of the limited resources available in prison; they establish daily routines that allow them to find meaning and purpose in their prison lives, lives that might otherwise seem empty and hopeless. The resilience shown by prisoners should not be construed as an argument for more or longer prison sentences or for more punitive regimes of confinement, but rather is a reminder that human beings can find meaning in adversity. Prisons are meant to be settings of adversity but should strive to accommodate the human needs of their inhabitants and to promote
\end{abstract}

Special Needs Offenders in Correctional Institutions, (2012): pg. 319-344. DOI. This article is C SAGE Publications and permission has been granted for this version to appear in e-Publications@Marquette. SAGE Publications does not grant permission for this article to be further copied/distributed or hosted elsewhere without the express permission from SAGE Publications. 
constructive changes in behavior. Here, there are programmatic offerings that may provide prisoners with the hope, skills, and empowerment necessary to overcome barriers to achievement and success as human beings in any social context. A current line of inquiry has focused on faith-based prison programs and the potential benefits that a deepened spiritual life might have on coping with the "doing time" experience, changing old lifestyles, and reducing the likelihood of people returning to prison. These points will be explored throughout this chapter.

\section{Introduction}

In the United States, where more than 1.6 million people are imprisoned in state and federal prisons and more than 400,000 work at them, prisons are big business (Bureau of Justice Statistics, 2009). As an abstract term, prison is quite simple: it's a place where a person's freedom, movements and access to basically everything is restricted, usually as punishment for committing a crime. But for anyone who has ever done hard time, a prison is so much more: it's a place where dignity, privacy and control are given up to guards and prison administrators, where isolation and boredom can drive someone insane, and where the simplest of necessities seem like luxuries. Life in prison has changed drastically in the past twenty-five years. As a result of changes in legislative responses to the "war on drugs" and judicial decision making, America outstrips every other nation in the world in the number of people it puts in its prisons. According to a study by the Pew Center (2008), one out of every 100 adults in the United States (U.S.) is in prison or jail. Prisons are more crowded, availability of educational and vocational programs is being reduced because of financial crises, and inmate on inmate violence is increasing.

When most people hear about unpleasant conditions in U.S. prisons, they don't feel particularly bad for the convicts. However, there has been a prison reform movement since, at least, the $1700 \mathrm{~s}$, when religious groups such as the Quakers objected to prison conditions. Reformers lobby for better treatment by guards, better equipped medical facilities, well-funded education programs and more humane treatment. These people aren't criminal sympathizers -- they simply have strong beliefs, for ethical or religious reasons, that even convicted criminals should be granted basic human rights. And, quite simply, the foundation upon which American prisons were created 
rested on the belief in the "perfectibility of people." There's another reason people want to reform prisons. More than 90 percent of all prisoners are eventually released (Petersilia, 2003). When they are released, often the only skills they acquired in prison were those that allowed them to survive. They may be paranoid or bitter. They may have learned that the only proper response to a problem is violence. Their social skills have atrophied. Getting a decent job as a convicted criminal is hard enough -- add in these factors and it can become very difficult for formerly incarcerated individuals to re-assimilate themselves into the outside world.

In looking for answers to the numerous challenges facing people who live or work in prison settings, the role of religion and spirituality continues to be a topic of great interest and controversy and is the focus of this chapter.

\section{Historical Overview}

The history of the United States corrections system is one filled with irony and a never-ending attempt to reduce crime through deterrence, incapacitation, and rehabilitation. While founded upon the humanitarian and religious ideals of redemption, reform, and reintegration, the United States correctional system has evolved into a mechanism by which society controls particular segments of the population it deems a "risk" to the public safety of communities. With 2.3 million people incarcerated in our nation's prisons and jails today as well as an additional 6 million persons on probation and parole, programming is critical.

Historically, religion in the United States has played a significant role in the reform efforts to rehabilitate criminals, largely because the deeply embedded Judeo-Christian concepts of repentance and redemption suggest that people are capable of moral regeneration. Indeed, the link between penology and religion in the United States can be traced to the 18th century when religious groups, such as the Quakers, began to enter prisons and presumably helped rehabilitate inmates by preaching their gospel. Under Quaker philosophy, a major goal of confinement was penance through required bible study and reflection on one's sins (Sumter \& Clear, 2005). In fact, the two 
earliest U.S. prisons, Auburn in New York and Eastern State Penitentiary in Philadelphia, were grounded on redemptive principles when they opened in the 1820s. Auburn, stressing redemptive discipline and hard labor, reflected what some see as the spirit of the "Protestant ethic." Eastern State Penitentiary, although later adopting the labor-discipline model, began as a Quaker experiment to create a system in which prisoners would be confined to their cells to study and receive religious instruction so that they might reflect on their offenses. Both systems were guided by an implicit notion of the malleability of human nature: Auburn, through changing behavior by instilling discipline, and Eastern State Penitentiary, by changing character through religious instruction (Johnston, 1994).

The influence of religion in prisons continued through the 19th century and into the 20th century, as prisons began including chapels in their design. By the mid-20th century, religion was recognized as an accepted program in virtually all U.S. prisons, and most prisons employed prison chaplains and allowed volunteer lay persons to tend to prisoners' religious needs. However, with limited exceptions, religious rights extended primarily to the two Christian doctrines of Catholics and Protestants. The growth of the Black Muslim religion in prisons set the stage for litigation demanding that non-Christians receive the same rights and privileges as people of other faiths (special diets, access to clergy and religious publications, opportunities for group worship). For example, in Fulwood $v$. Clemmer (1962) ${ }^{1}$, the U.S. District Court of the District of Columbia ruled that Black Muslims have the same right to practice their religion and hold worship services as do inmates of other faiths. In 1963, the Warren Court handed down its landmark decision in Cooper v. Pate $(1964)^{2}$, which resurrected 19th-century civil rights legislation and provided the legislative justification for redressing state civil rights complaints in federal courts. This opened the door for litigation challenging restrictions on prisoners' right to practice religion. In Cruz v. Beto $(1971)^{3}$, the court further expanded protected groups in ruling that a Buddhist prisoner must be given a "reasonable opportunity of pursuing his faith comparable to the opportunity afforded fellow prisoners who adhere to conventional religious precepts." permission has been granted for this version to appear in e-Publications@Marquette. SAGE Publications does not grant permission for this article to be further copied/distributed or hosted elsewhere without the express permission from SAGE Publications. 
The rights of some religious groups were curtailed by prison administrators' fears that prisoners were using religion as a ploy for political action, as a shield for gang activity, or as a means to obtain illicit resources. For example, up to the 1970s, many prison administrators continued to believe that Black Muslims were primarily a radical political group posing as a religion, and they did not grant them the benefits accorded to persons who practiced conventional religions. Other prisoners creatively attempted to establish idiosyncratic religions with esoteric needs as a means of acquiring resources, such as "ritualistic" wine, steak, and less restricted access to sex. Although litigation on such trivial grounds were often dramatized by the media and prison officials hostile both to prisoners and their litigation, such cases were relatively infrequent and quickly dismissed by the courts.

Litigation to expand the religious rights and privileges of prisoners led some critics to argue that the judiciary, not prison administrators, had gone too far and that prisoners could easily circumvent prison rules simply by invoking a religious premise. However, case law applies the reasonableness test to inmates' right to practice their religion with regard to the special security needs of prisons. The U.S. Supreme Court has found such restrictions appropriate as long as they are necessary to further legitimate penological objectives (see O'Lone v. Shabazz, 1987, and Turner v. Safley, 1987). ${ }^{4}$

In the past 20 years, Muslims, Orthodox Jews, Native Americans, Sikhs, Rastafarians, Wiccans, and other groups have gained some of the rights considered necessary for the practice of their religions and have broken new legal ground in First Amendment issues. Court decisions have upheld prisoners' rights to be served meals consistent with religious dietary laws, to correspond with religious leaders and possess religious literature, to wear a beard if one's religious belief requires it, and to assemble for religious services. Federal and state governments have contributed to the expansion of legitimate religious groups and practices in prisons by enacting legislation that, although intended primarily to protect the religious rights of free individuals, have also expanded those of prisoners. 
Today, a variety of groups are actively involved with prisoners in an attempt to address their offending behavior as well as offering support. Furthermore, such ministry is not confined to Christianity though this religious orientation dominates in prisons with aggressive and well-organized proselytizing and promoting Christian values in the integrated content of programs. For example, Florida's faith-based prisons have been criticized for building prison programming and control around denominational precepts (Besen, 2004). Prison Fellowship Ministries, the largest and best known organization, has developed partnerships with at least four states to implement Christian-based programs intended to provide a model for other prisons (Nolan, 2002). Brazil's Humaita Prison was designed to turn the prison into a Christian community, reportedly with some success (Johnson, 2002). The Baptist Experiencing God program in Angola prison is given credit for reducing violence, escapes, and providing stability to the inmate culture (Frink, 2004).

\section{Contemporary Role of Prison Religion}

The fact that religion is now on the national criminological agenda resulted from a complex set of factors: (1) the growth of the Restorative Justice movement which often draws on biblical notions of justice (Johnston \& Van Ness (2006); (2) the widespread appeal of Native American, Christian, Islamic, and other religious practices such as Transcendental and Buddhist meditation among prisoners (O'Connor \& Pallone, 2002); (3) a call from the U.S. Catholic Bishops for an end to the death penalty (U.S. Catholic Bishops, 2000); (4) the passing in 2001 and upholding by the Supreme Court in 2006 of the Religious Land Use and Institutionalized Persons Act (RLUIPA) that substantially strengthened the constitutional right of people to practice their religion in prison; (5) President Bush's faith-based initiative; (6) and the growth of faith-based prisons or prison units around the country in Alaska, Iowa, Louisiana, New Mexico, Texas, Florida, Ohio, Kansas, the Federal Bureau of Prisons as well as in other countries such as Brazil and England (Burnside et al., 2005). 
NOT THE PUBLISHED VERSION; this is the author's final, peer-reviewed manuscript. The published version may be accessed by following the link in the citation at the bottom of the page.

\section{Prison Ministry}

\section{A. Chaplains}

Religion has always played a vital role in corrections. Throughout history, Catholic priests, Protestant pastors and an occasional Jewish rabbi were available to inmates. Faith and religion have often been important sources of strength for those caught in the criminal justice system. Most of the direct influence of religion in corrections has been accomplished through the work of correctional Chaplains.

Early prison Chaplains in the United States held positions of relative importance which is not surprising considering they were part of a system created by religious groups. They were responsible for visiting inmates, providing services and sermons, and also served as teachers, librarians, and record keepers. At times, the Chaplain might also act as an ombudsman for the inmates when issues of maltreatment would arise. Chaplains were not always welcome in correctional facilities as they were viewed as being naive and susceptible to inmate manipulation. In fact, during the development of the reformatory, many prison administrators considered Chaplains to be a hindrance to running a prison. However, the Clinical Pastoral Education Movement of the 1920s and 1930s resulted in the reemergence of prison chaplaincy in a positive light. The professionalization of prison chaplaincy work was evident in the organized methods of study and dissemination of the gospel by competent professional Chaplains who were able to meld their work as yet another form of applied rehabilitation. Today, it is common that the prison Chaplain is an educated and multi-skilled person who is generally accepted as helpful by the diverse groups of individuals who live and work in the prison setting.

By the laws of the Religious Freedom Restoration Act instated in 1993, states are obligated to the best of their abilities to accommodate the spiritual needs of its incarcerated population. Muslims, Christians, Jews, Buddhists, Wiccans, Native Americans, and a wide variety of other religious groups practice their rituals under one roof, often within inches of each other. Most of the groups are led by State employed 
chaplains and sometimes by civilian volunteers who have overcome fears, stereotypes and prejudices, to pray and heal with individuals and groups of inmates. Prison chaplaincy services may provide a benefit in lowering facility infractions and reducing recidivism (Rioux, 2007). There is growing evidence to support the efficacy of cognitivebehavioral programs in the correctional environment; however, few formal studies have been conducted on faith-based cognitive programs (Hall, 2003).

Currently, the widespread financial crisis affecting so many state governments has created a situation of uncertainty for the future of prison chaplaincy. As states have been forced to cut overall spending, some of them have also eliminated state paid prison chaplains from their organizational charts. The rationale given by some legislators in these states is that religious services can be provided by volunteers at no cost. This reasoning reflects a limited understanding of the chaplain's role as one who only provides worship services and sacramental rites, but it overlooks important issues such as facilitating the constitutional rights of all offenders to practice their religion and providing skilled pastoral care. In the long run, these roles and others may save the state more money in terms of fewer lawsuits and providing effective treatment programs.

\section{Potential Bumps in the Religious Road to Redemption}

State budget crises are forcing states to search for ways to cut prison costs. Their choices include allowing privately sponsored evangelical prison ministries to replace chaplains at lower costs or for free, dropping below the national standard of one chaplain per 500 prisoners, or replacing the paid chaplains with volunteers. Colorado recently replaced all the chaplains in its state prisons with an evangelical Christian prison ministry that offered services for free. In Texas, lawmakers cut 62 state prison chaplain positions in 2003, a 40 percent reduction. In Georgia, legislators are considering a proposal to replace state-funded chaplains with volunteers.

Evangelical Christians are moving into cash-strapped state prisons to supplement and, in some cases, replace existing chaplain services. Their mission is answering Jesus' call to visit the imprisoned 
and recognizing the power of faith to transform troubled inmates into productive citizens. Their work is supported by private donations and encouraged by the government's emphasis on faith-based social services. Correctional officials say they are grateful for the free or lowcost help. But many people challenge the fairness and legality of giving one religious group unusual access to prisoners.

Critics say evangelicals have a conflict: Their faith tells them to win converts, but the law requires prisons - and those who work there - to respect and even encourage the inmates' own religious beliefs, whatever they are. Some inmates, professional chaplains and nonChristian religious leaders accuse evangelical Christians of barring prisoner access to non-evangelical ministers and of forcing inmates to endure evangelizing. Some prison programs grant special privileges for those who profess Christian beliefs. A federal judge in Iowa has ruled that the Bible-based prison program, InnerChange Freedom Initiative (an organization with ties to Charles Colson's Prison Fellowship Ministries), violated the First Amendment's freedom-of-religion clause by using state funds to promote Christianity to inmates (Hughes, 2006). The decision has set the stage for an appeals process that is expected to explore more broadly the constitutionality of the Bush administration's religion-based initiative programs.

People of faith care about them, and evangelical Christians have been particularly attentive to the needs of inmates and their families. Nearly everyone agrees that religion can bring discipline, focus and purpose to prisoners' lives. Yet religion isn't accepted as a cure-all, and many see dangers in what they perceive as either the under- or overuse of it in prison. Experts are divided over whether there is solid evidence that religious programs do a better job rehabilitating prisoners than do secular ones (Mears, 2007). Many worry that chaplaincy cuts may deprive inmates of spiritual support, while others worry that faith will be illegally foisted on this captive audience.

\section{B. Prison Ministry Work}

The purpose of incarceration is to attempt to reform people and not to punish them vindictively. The word "penitentiary" derives from the notion of prison as a place where the imprisoned may reflect on 
their misdeeds and repent of them (i.e., be penitent). This dovetails neatly with the religious concept of changing one's life through conversion. The conversion experience is stressed most emphatically in evangelical Christianity. Prisoners who are Jewish or Islamic, or who adhere to other non-Christian religions, face the problem of unfamiliarity. Special needs related to their religious observances such as holidays and dietary laws - may or may not be accommodated gladly. Therefore, it is not surprising that in recent years, prison ministry has become primarily the domain of evangelical Christians. Today's prison ministries tend to seek reform of individual prisoners, not the criminal justice system.

Christian involvement to those men and women behind bars falls into five general areas of ministry: evangelism, on-going discipleship (to include counseling), follow-up to ex-prisoners, providing full and part-time Chaplains and ministry to the families. All prison ministries rely heavily upon the local religious community to provide volunteers to energize the outreaches they offer. The vast majority of these ministries exhort, equip and assist the volunteer in their ministry to the prisoner. Of the five areas, by far the most emphasis is placed on evangelism. A variety of faith-based programs have been offered in the prison setting as well as in the community. Below is a sampling of programs that have gained nationwide attention:

Aleph Institute (http://aleph-institute.org/help.htm) - The mission and purpose of Project H.E.L.P. is the rehabilitation of inmates and improved family, social, and work ethic accomplished by behavior modification modalities that integrate principles of Jewish law and tradition with psychological principles. The program will integrate religious/spiritual, educational/vocational, therapeutic, and case management services to create a comprehensive approach to helping the inmate and her/his family. They provide assistance to Jewish and non-Jewish prisoners who request their assistance.

Kairos Prison Ministry International (http://kairosprisonministry.org/) - has three (3) programs that address the spiritual needs of incarcerated men, women, and children, and to their families and to those who work inside prisons. The permission has been granted for this version to appear in e-Publications@Marquette. SAGE Publications does not grant permission for this article to be further copied/distributed or hosted elsewhere without the express permission from SAGE Publications. 
interdenominational team of volunteers - both clergy and laypersons works in cooperation with the prison Chaplain to select participants. Kairos "Inside," "Outside," and "Torch" programs currently operate in hundreds of prisons and communities throughout the U. S. and abroad. More than 170,000 incarcerated men and women have been introduced to Kairos, since its inception, and over 20,000 volunteers donate their time and resources for this effort.

Prison Fellowship (http://www.prisonfellowship.org/ contentindex.asp?ID=87) - partners with churches across the United States - and around the world - to share the love of Christ and serve the special needs of prisoners, ex-prisoners, and their families, including the children. The organization provides several programs for inmates and their family members including "Angel Tree" that serves the children of prisoners in various capacities and includes programs like Angel Tree Christmas, Angel Tree Camping, and Angel Tree Mentoring; the "Pen Pal Program" matches prisoners with someone on the "outside" to write to them regularly and offers encouragement and emotional/spiritual support, but cannot help with financial or legal needs; "Inside Journal" is Prison Fellowship's newspaper that is produced for incarcerated women and men in state and federal prisons in the United States and includes encouraging articles on ex-prisoners who are now succeeding in life, profiles on celebrities who have a vibrant faith in Christ, helpful Bible studies, guidance on making the most of prison time, information on preparing for release from prison, current news that relates to prisoners and the criminal justice system, and some humorous pieces just for fun.

Prisoner \& Family Ministry (http://www.Issi.org/IssiPublic/ publicsite/pfm_detail.asp) - Lutheran Social Services of Illinois (LSSI) provides several programs to incarcerated women including "Visits to Mom" that transports children to every Department of Corrections facility housing women, through their corps of volunteer drivers and via monthly bus trips; "Relatives as Parents Program" that is a support group for grandmothers and other caregivers; "Re-Connections" provides a place where newly-released women are given encouragement and referrals to community resources and services that address their needs; the "Storybook Project" provides books and tape recorders to inmate mothers so they can record and mail stories permission has been granted for this version to appear in e-Publications@Marquette. SAGE Publications does not grant permission for this article to be further copied/distributed or hosted elsewhere without the express permission from SAGE Publications. 
to their children on tape; LSSI's Building Homes: Rebuilding Lives program where homes are built for economically disadvantaged families using walls built by prisoners at the Hardin County Work Camp who participate in this program.

What all of these faith groups would appear to have in common is a fervent belief that people can change. The normative prescriptions for restoration of the human spirit are taught routinely in churches and synagogues. It is no wonder, then, that religious institutions have come to acquire a certain "ownership" of the problem of deviance and its moral remedy. Concerted rehabilitation efforts have been funneled into a wide variety of prison ministries. There are literally thousands of small, independent churches and religious organizations that operate prison ministries today. Services provided by prison ministries range from the distribution of Bibles and other religious materials to more comprehensive programs such as family counseling, legal aid, and victim-offender reconciliation/mediation. In spite of these efforts there are concerns regarding the role of religion within prison. For some, these concerns focus upon the economics of overcrowded prisons, with resources stretched to breaking point it is feared that the government is allowing charitable organizations to take over their role. Others fear that prisoners' inherent vulnerability leaves them liable to be swayed by the tangible benefits religious groups are able to offer, leaving little real choice for the individual.

\section{The Separation of Church and State Debate}

Faith and religion play a complex and controversial role in the criminal justice system. From the growing number of Christian ministries and bible-study groups in prison to church-based inner city programs for ex-prisoners to the recent controversy over the role of posting the Ten Commandments in public spaces, the influence of faith and religion, especially Christianity, is visible in all aspects of the legal and criminal justice systems. And while faith and religion have often been important sources of strength for those caught in the criminal justice system, critiquing the role of faith becomes tricky. When is faith empowering and when is it being used to oppress? Should we fight for increased religious access or a ban on the practice of religion in the criminal justice system? The positive role faith and religion may

Special Needs Offenders in Correctional Institutions, (2012): pg. 319-344. DOI. This article is (C) SAGE Publications and permission has been granted for this version to appear in e-Publications@Marquette. SAGE Publications does not grant permission for this article to be further copied/distributed or hosted elsewhere without the express permission from SAGE Publications. 
play in an individual's life must be balanced with the reality that some spiritual conversions occur in the name of improved living conditions (e.g., faith-based pods) as compared to true individual change(s) and that some religious programming may occur as the manipulation of faith to push a conservative cultural and policy agenda which must be exposed and resisted.

The rise of the religious, or "faith-based," prison at the turn of the twenty-first century bears witness to the remarkable resilience of religion in shaping the philosophy of punishment. It seems that most of the attention over the past 2-3 decades has focused on Prison Fellowship Ministries, started by former Watergate figure, Chuck Colson. In the beginning, it sought no outside funds from government, instead focusing on grass roots organizing through churches and lay ministries. Early efforts focused on volunteers visiting prisons to spread the word. It evolved into prison ministry, with training for volunteers who would serve as mentors to the incarcerated and eventually assist former prisoners with their re-entry. Critical shortages in prison funding for programming assisted the growth in acceptance for prison fellowship among criminal justice professionals. The program continued to evolve to the point of proposals to run entire wings of some prisons. In the last decade, prisons that incorporate religion in various ways have sprouted around the country - in Florida, Iowa, Kansas, Minnesota, and Texas - and there are some indications, though preliminary, inconclusive, and hotly contested, that inmates who participate in religious instruction and "programming" recidivate at significantly lower rates than those who do not. The early success of these programs (and, some say, the preferential treatment accorded to participants in them) has resulted in high demand and long waiting lists. Florida has recently opened its second faith-based prison, this one for women, and more such programs are presently being planned and implemented. Religious prisons raise very serious questions of constitutionality and effectiveness, and most of the critical commentary to date has focused either on the various complicated Establishment Clause concerns or the programs' inconclusive recidivism results.

Criminologists, scholars and civil liberties groups have warned against expanding faith-based prison programs, citing questions about permission has been granted for this version to appear in e-Publications@Marquette. SAGE Publications does not grant permission for this article to be further copied/distributed or hosted elsewhere without the express permission from SAGE Publications. 
their constitutionality and effect on prisoners' behavior. Some expert's dispute claims that faith-based rehabilitation leads to fewer future arrests. Others have questioned whether such programs amount to special treatment for religious prisoners or proselytizing. One major concern expressed by critics of expanded religious programming focuses on the additional benefits provided to participants by the religious programs. For example, volunteer inmate participants in the InnerChange Freedom Initiative receive Bible and Computer classes, mentors from local congregations and the promise of post-release jobs (Nolan, 2002). While participation in InnerChange does not require participants to be Christians, they must participate in all of the programs, which centers on the transforming power of Jesus. Because of these additional benefits, critics are justifiably concerned that in order for inmates to receive these benefits, program participants are exposed to only one religious philosophy, thereby endorsing a Christian religion over the other religious faiths. Other critics wonder why an inmate must embrace religion in order to receive benefits that have been shown to reduce recidivism, such as vocational/educational training, mentorship, family counseling, and job placement. If programs such as InnerChange due show positive results in reducing recidivism, there still remains questions whether the outcome is the result of religious conversion, the result of educational/vocational programming, mentorship or other forms of social support, or some combination thereof.

\section{Doing Prison Time}

Inmates in today's prisons do not serve their terms in isolation. Rather, prisoners form a society with traditions, norms, and a leadership structure. Some members of this society may choose to associate with only a few close friends (Jones \& Schmid, 2000); others form cliques along racial or "professional" lines (Carroll, 1974). Still others may be the politicians of the convict society; they attempt to represent convict interests and distribute valued goods in return for support. Just as there is a social culture in the free world, there is a prisoner subculture on the "inside." Membership in a group provides mutual protection from theft and physical assault, the basis of wheeling and dealing activities, and a source of cultural identity (Irwin, 1980). The inmate subculture helps inmates cope with the challenges,

Special Needs Offenders in Correctional Institutions, (2012): pg. 319-344. DOI. This article is C SAGE Publications and permission has been granted for this version to appear in e-Publications@Marquette. SAGE Publications does not grant permission for this article to be further copied/distributed or hosted elsewhere without the express permission from SAGE Publications. 
frustrations, deprivations, and pains of imprisonment that are part of the prison experience (Sykes, 1958). These deprivations are somewhat alleviated or neutralized through a collective response, which is in clear-cut opposition to the desires of prison officials.

Various factors affect the extent of an inmate's assimilation into the prison culture. These include personal characteristics such as age, race, marital status, socioeconomic status, educational attainment, and extent of criminal involvement (Drowns \& Hess, 1995). Clemmer (1958) found that inmates incarcerated for short periods, such as a year or so, were neither assimilated into the prison culture nor had they become prisonized. Most people can endure deprivations for short periods of time because they can see an end to their torment. For those facing long sentences, prison becomes home. For many, faced with years behind walls, life becomes a strategy for survival. To make it in this environment, inmates must adapt to its more unpleasant features (Zaitzow, 1999).

Most prisoners hope to adapt quickly to prison culture, do their time, and leave. For them, the short prison stay may be insufficient to motivate any significant personal transformation. Prisoners who serve longer sentences have different adaptation mechanisms and, for them, adaptation is a longer, more complex process. For some, adaptation entails reinforcing behavior patterns that are counter-productive and debilitating. For others, adaptation entails withdrawal. However, for a small but significant group, a personal transformation occurs in which they admit their offenses and attempt to redirect the focus of their life by transforming themselves and helping others through the study and practice of religious precepts.

\section{Doing "Religious/Spiritual" Time}

Prisons have real consequences for the people who enter them. When prison environments lack effective programming and treatment, allow for the persistence of dangerous and deprived conditions of confinement, and continue to use forceful and/or potentially damaging techniques of institutional controls, the people who reside in those environments are impacted by the harmful and destructive effects or

Special Needs Offenders in Correctional Institutions, (2012): pg. 319-344. DOI. This article is C SAGE Publications and permission has been granted for this version to appear in e-Publications@Marquette. SAGE Publications does not grant permission for this article to be further copied/distributed or hosted elsewhere without the express permission from SAGE Publications. 
consequences of such exposure. For short and long-term prisoners, the incarceration experience takes a unique toll.

People often turn to religion or (re)discover a spiritual identity in times of crisis, like while lying in a hospital bed with a critical illness or while holding on for dear life during an earthquake. These moments can instantly illuminate the frailty and brevity of life, causing a sudden realization of our dependence on some type of spiritual core. One might question the authenticity of a faith conversion made in such dire circumstances: Is the decision genuine or is it spurred only by fear in a last ditch effort to "make it into heaven?" As one can imagine, a similar phenomenon happens behind prisons walls - to such an extent that it's been coined "jailhouse religion." Such life-changing events may be short-lived or such spiritual awakenings may, indeed, last a lifetime. But, it is important to understand the level of spiritual commitment in order to minister to men and women in prison.

Religion can serve, at least, four roles in prison. First, it provides answers to the prisoner's questions about life. Second, it provides rules to adhere to, which makes inmate management easier. Third, it is experiential. In other words, something intrinsic takes place (salvation or conversion) which is evident to the inmate and later to those around him/her. Finally, religion plays a social role bringing together like-minded inmates for worship, Bible study and other faithrelated activities. This togetherness gives the inmate a sense of belonging and positively impacts the prison's culture.

There is evidence that religion helps make prisons more manageable. In one study, the researcher found that prisoners often seek God to cope with inmate life, which is marked by depression, guilt and self-contempt. Here, highly religious inmates evidence lower rates of depression and commit fewer disciplinary infractions than other inmates (Clear, 1992). In another study, correctional officials from three states credited Prison Fellowship's religious programming with improved morale, lower rates of depression and fewer disciplinary infractions. Administrators generally agree that programs are important in dealing with the problem of time on the prisoners' hands. They know that the more programs prisons offer, the less likely inmate idleness turns into hostility. Prisoner religious organizations present a permission has been granted for this version to appear in e-Publications@Marquette. SAGE Publications does not grant permission for this article to be further copied/distributed or hosted elsewhere without the express permission from SAGE Publications. 
unique opportunity to channel inmates' energies and use their talents in meaningful and beneficial ways (Fox, 1982).

\section{Conning or Conversion: Does It Really Matter?}

While some inmates, staff, and members of society share the belief that inmates practice religion to manipulate or "con" others into early release decisions or to influence Wardens or Chaplains to improve prison living conditions, prisoner religious organizations present a unique opportunity to channel inmate energies and use their talents in meaningful and beneficial ways (Thomas \& Zaitzow, 2006).

\section{A. Psychological-Emotional Benefits}

It is difficult to determine the motivations for prisoners' involvement with religious programs while incarcerated. This difficulty is caused by the fact that religious belief and practice is an individual matter and exacerbated by the psychological complexities of living in prison. In some cases, the person may simply be practicing their faith. Here, they may have grown up practicing a religion, joined a religion later in life, or developed the interest during incarceration. Their faith can provide them with a direction that is better than their present psychological or physical condition on "the inside."

For others, the trauma of life events (e.g., incest and domestic violence) may have been the precipitating force behind their drug addictions. For this group of individuals, prison programs have little to offer incest survivors; they are mostly left on their own to reflect on their life experiences and support each other to heal. In such cases, inmates may gain direction and meaning for their life from the practice of religion while in prison.

Religion also provides hope for incarcerated men and women the hope to reform from a life of crime and from a life of imprisonment may give them "peace of mind" and/or some level of personal contentment. This is especially important to the well-being of those serving long sentences (Zaitzow, 2006). permission has been granted for this version to appear in e-Publications@Marquette. SAGE Publications does not grant permission for this article to be further copied/distributed or hosted elsewhere without the express permission from SAGE Publications. 
Incarcerated women and men may opt to become involved with a faith-based program to improve their self-concept. Because the core of many religious beliefs includes acceptance and love from a higher being - and from members of the faith group - those who suffer from guilt related to failures in life, remorse for criminal acts, or from the pain of a dysfunctional family background, may feel better about themselves if they practice religion while incarcerated.

Finally, some inmates have committed horrific crimes which make them outsiders within the prison world and often subject to attacks by other inmates. Participation in a faith-based program can provide them with the social support that would not otherwise be available to them in prison (Jones, 2006).

\section{B. Practical-Material Benefits}

The serious practice of religion typically involves self-discipline, self-introspection, and concern for others to follow the principles associated with one's faith. Learning and practicing such self-control helps inmates avoid confrontations with other inmates and staff that might otherwise result in a negative response. Moreover, it helps them comply with prison rules and regulations.

There are additional reasons why prisoners might become involved with prison religious programming. Depending on the prison, some may believe that membership in a religious group will provide protection from some of the negative features of prison life like physical confrontation, sexual exploitation, and/or blackmail. The presumed "safe" territory of the prison chapel may be a refuge for those who wish to escape the day-to-day frustrations associated with living in prison. Further, affiliation with religious groups may facilitate new friendships among the inmate population as well as the opportunity to meet male and female volunteers who visit the prison to conduct religious services. Moreover, such affiliations may result in access to special resources that are difficult or impossible to obtain while incarcerated. For example, food and drink that may be offered at the religious service may be an incentive for people to attend services. In addition, free goods/materials (e.g., books, music, holiday and greeting cards) may be given to inmates as a means by which they

Special Needs Offenders in Correctional Institutions, (2012): pg. 319-344. DOI. This article is C SAGE Publications and permission has been granted for this version to appear in e-Publications@Marquette. SAGE Publications does not grant permission for this article to be further copied/distributed or hosted elsewhere without the express permission from SAGE Publications. 
may continue their religious training after the volunteers have departed.

There are many men and women "doing time" in our nation's prisons (and jails) who do a lot of community service work so that they can heal and reconnect with the community and, perhaps atone for their crimes. They may feel remorse and hope that the community will accept their new efforts. Many are determined to contribute to society. They transcribe educational materials for the blind and read books into tapes for the blind (Prison Braille Program). They train puppies to serve as helpers for the mobility-impaired in the community (Pathways to Hope Prison Dog Project) and support a variety of community projects throughout the nation. The Jaycee program at the Minnesota Correctional Facility in Stillwater raises money to combat Muscular Dystrophy. Or during natural disasters, prisoners can often be found filling sand bags or doing other work to help save communities from flooding waterways. Sadly, we rarely hear about such positive efforts as the media is busy catering to the fast-food mentality of the citizenry and stories of pain, endurance, and redemption are not often viewed as big sellers.

As a society, we must promote and embrace policies and practices that support the reality that women and men are different and diverse but that each group's needs can be addressed during their imprisonment as well as upon their release. There is a need for networking between agencies and groups to partner with incarcerated populations and prison administrators to create pastoral and public policy reforms that address the specific needs of the incarcerated and their families.

\section{The Power of Faith/Religion in Prison}

As long as there have been prisons, religious education and training have been a staple of prison life. Religious programs for inmates are not only among the oldest but also among the most common forms of rehabilitative programs found in correctional facilities today. Previous research has focused largely on incarcerated males and traditional measures of religiosity such as participation in religious-based activities while incarcerated (Clear \& Sumter, 2002). permission has been granted for this version to appear in e-Publications@Marquette. SAGE Publications does not grant permission for this article to be further copied/distributed or hosted elsewhere without the express permission from SAGE Publications. 
While more recent research has examined incarcerated individuals, their offenses, and religious/spiritual orientation (Fernander et al., 2005), there is a paucity of systematic research on the relationship between prison religious practice and key outcomes important to a rehabilitative or correctional framework for diverse populations. The limited empirical research that does exist has tended to examine the effects of religious programs in a prison setting on outcomes such as institutional behavior and recidivism. For example, an exploratory study by Sumter (2000) did examine the effect of inmate religiosity on post-release community adjustment. Findings indicated that inmates who reported high levels of belief in the supernatural were less likely to be arrested after release. Another study by Johnson, Larson, and Pitts (1997) evaluated the impact of religious programs on institutional adjustment and recidivism rates upon release. They found that inmates who were most active in Bible studies were significantly less likely to be arrested in the following year after release.

More recently, according to one prison chaplain, recidivism is reduced by half for persons who participate in a weekly faith-based activity (Rioux, 2007). Other administrators report observable behavioral improvements among incarcerated persons with the expansion of faith-based programs. For example, in a southeastern prison, religiosity among residents was associated with reduced verbal and physical conflicts and prosocial behavior (Kerley et al., 2005). Clear and Sumter (2002) report that religiosity among the incarcerated is helpful in modifying behavior as well as psychological states. In their study, higher levels of religiosity were linked to enhanced psychological adjustment and fewer self-reports of disciplinary confinement. In a review by O'Connor and Perryclear (2002) of studies which examined the outcomes (e.g., prison infractions, adjustment, recidivism) of prison religious involvement, the researchers concluded that while the effects were modest, there were questions regarding methodological weaknesses that rendered the findings inconclusive.

Little is known about the process of offender rehabilitation or why some offenders desist in their criminal careers. Maruna (2001) describes a phenomenology of reform in which the individual's transformation of self entails leaving the past behind (that selfish, hedonistic, immoral criminal) and replacing it with the new self who permission has been granted for this version to appear in e-Publications@Marquette. SAGE Publications does not grant permission for this article to be further copied/distributed or hosted elsewhere without the express permission from SAGE Publications. 
cares for others and has new goals, aspirations and actions. Whether in the context of "finding God," "being born again" or simply "finding personal peace," the transformation process for people of all religious and spiritual beliefs involves a recasting of oneself. More research is obviously needed to explore these intriguing findings which have implications for the reintegration of formerly incarcerated people into the community and most importantly, for their reformation as lawabiding citizens.

Although religious services have long been a staple of prison life, officials across the nation are beginning to realize just how important faith can be in promoting the rehabilitation of inmates and managing the increasing numbers of people in prison. Many prison officials report that religious activities are widely popular and successful. Thus, it is not surprising that increasing theoretical attention has focused on the use of such programs in a correctional institution as well as a resource for reentry efforts (O'Connor, 2004, 2004-2005; Thomas \& Zaitzow, 2006).

\section{The Continuation of Redemption Upon Release}

There is an abundance of research that documents the structural impediments to post-prison success resulting in numerous legal restrictions and economic difficulties (Richards \& Jones, 2004; Petersilia, 2003). Roughly two-thirds of all prison inmates recidivate within three years of their release from prison (Austin \& Irwin, 2001). This statistic is often used as a measure of the intractability of criminal behavior or as a failure of the criminal justice system in rehabilitating criminal offenders. Two structural factors have been identified as key to the successful re-entry of ex-prisoners into the free world. Those two factors are obtaining meaningful employment and maintaining a strong social support network. Although there is some empirical evidence that religious involvement may enhance inmates' adjustment and coping in prison (Clear et al., 1992), there is little research to document the role of religious commitment and participation in facilitating a successful community reentry.

Anecdotal evidence reinforces what many prison researchers have known for years: one of the greatest fears many inmates have is permission has been granted for this version to appear in e-Publications@Marquette. SAGE Publications does not grant permission for this article to be further copied/distributed or hosted elsewhere without the express permission from SAGE Publications. 
being released. Typically, if an inmate has no family or support group to meet them at release, the state transports them to the local greyhound station and/or capital city. Before the van drives away, the inmate is given approximately $\$ 100$, a duffle bag with their meager personal effects, and the clothes worn on their back at the time of imprisonment. In effect, men and women are set up to fail without any means for obtaining transportation, lodging, food, clothing, or employment. Imagine the fear and anxiety of being thrust into this situation when for the past several years of life, your schedule has been determined for you while in prison. Food, clothing, shelter, recreation, education, and even menial work responsibilities - all has been provided for you up until this time. Now you are responsible to provide those essentials of life for yourself without any knowledge or skills to do so. As simple as these everyday responsibilities are for those on the outside, it becomes a complete culture shock for the now ex-prisoner. Unfortunately, many believe they have no alternative other than the life they know how to live. Many have already been rejected by family and friends. Some are caught in a "revolving" door, out of prison only to go back into prison. They are powerless to change in their own strength. They go back to the same neighborhood, the same way of life, the same temptations and find their personal strength and determination fails them.

Participation in faith-based programs may strengthen social norms through the identification and reinforcement of values, attitudes, and beliefs. This, in turn, may also serve as a social support mechanism in helping men and women to overcome the challenges associated with reintegration upon release. The great need in the lives of people behind prison walls - and those who will soon return to their communities - is hope. Faith-based programming may be the means by which hope is instilled in the hearts and minds of formerly incarcerated men and women. Believers in some spiritual core, who are released from prison, need a support network of a local church body that will care enough to offer fellowship, encouragement and a way to grow in their faith, as well as help them in practical ways with physical needs. The transition period from the old way of doing things into the new way of life must be supported by the local church or organization that provides the instruction. Newly released community members need friends who will counsel and encourage them in the permission has been granted for this version to appear in e-Publications@Marquette. SAGE Publications does not grant permission for this article to be further copied/distributed or hosted elsewhere without the express permission from SAGE Publications. 
religious/spiritual life they feel most comfortable with, the jobs they will need to seek out to be able to provide for themselves and their family. They need to know they can make it.

The successful transition from life in jail or prison to life in the community, has profound implications for increasing public safety by reducing offender recidivism. A key way to accomplish that goal is to institutionalize the cross-agency and community teamwork needed to make reentry succeed. Reentry efforts must begin in the prison and be actively carried into the community after prisoners are released. Services need to be tailored to prisoners' needs that help them reintegrate into society. Many practitioners agree that an active link between in-prison services and community services requires an involved mentor, case manager, or steering committee. Many of the prisoners that reentry initiatives work with must be taught how to interact with the. Here, religion or spirituality may serve a variety of functions that may expedite the successful reintegration of the formerly incarcerated into society.

As correctional departments face increasing costs for an expanding array of inmate needs, budgets are stretched to the maximum. In some jurisdictions, this has resulted in a reliance on faith-based organizations even though very little research has been conducted to assess offender outcomes after receipt of services by faith-based providers. A growing number of correctional administrators and community reentry experts have found that faith-based organizations can provide much-needed services to offenders through volunteers. These in-prison and community services are important because, prior to release, they may prepare prisoners to more easily use the community services that will aid in their transition after release. In addition to offering in-prison programs, faith-based organizations often help prisoners' families. Faith-based groups can provide assistance that reflects the values of the community where the offender will live upon release. Because they are part of the community, faith-based volunteers may offer invaluable knowledge and assistance to offenders who are trying to manage transportation, housing, employment assistance, and health issues. permission has been granted for this version to appear in e-Publications@Marquette. SAGE Publications does not grant permission for this article to be further copied/distributed or hosted elsewhere without the express permission from SAGE Publications. 
The need for faith-based organizations to be involved in prisoner reentry initiatives is widely recognized by local, state and federal prison systems. As criminal justice professionals continue to develop strategies to reduce recidivism, it has become more apparent that the likelihood of success without the substantial involvement of faith-based organizations is unrealistic. Nationwide, states face huge budget deficits. Spending on prisons make up the largest (or close to the largest) portion of state expenditures. In order for states to begin chipping away at looming budget deficits it is critical to reduce spending on prisons. Reducing recidivism is a critical part of any state's formula for reducing spending.

Indeed, the desire of many states to reduce recidivism is fueled to a great degree by finances instead of compassion. Departments of correction are coming to the conclusion that in order to be successful in keeping people out of prison, they must establish real partnerships with agencies and organizations in the community, including churches, synagogues, and other faith-based organizations. Aside from the financial problems faced by states, many have come to realize that certain aspects of reentry, such as family reunification, are best left to faith-based and community organizations.

In response to lawsuits, federal receivership of its medical, mental health and juvenile justice systems, and pressure from the federal courts to immediately reduce massive overcrowding, it is inevitable that reducing prison overcrowding will entail expanding community-based alternatives to incarceration. Here, it is a wellknown and documented fact that religious communities like churches and other faith-based organizations are seen as "first responders" to any crisis (Oppenheimer et al., 2004). Faith-based groups have a significant role to play in the re-entry process in their communities, since offenders and their family members often turn to them for immediate assistance and advice on accessing services. Therefore, as communities nationwide prepare to move thousands of prisoners into community re-entry programs, faith-based organizations need to be prepared not only to provide services, but to actively participate in developing its capacity to impact public policy. More importantly, churches and other faith-based programs need to provide strong, supportive, welcoming and caring environments that can help recently permission has been granted for this version to appear in e-Publications@Marquette. SAGE Publications does not grant permission for this article to be further copied/distributed or hosted elsewhere without the express permission from SAGE Publications. 
released prisoners (and their families), take the initial steps toward community re-engagement.

Most offenders return to their communities with multiple, cross systems levels of needs; i.e. lack of adequate job skills, safe housing, and - the number one predictor of parole success or failure - substance abuse. Relapse to drug use is common for all recovering individuals, and offenders suffer from stresses more numerous and intense than those affecting the typical treatment patient. Many offenders, even those rare few who have received some type of in-custody treatment and/or education and are motivated to follow aftercare recommendations, are unable to maintain abstinence when faced with a myriad of difficult decisions with little or no positive support. Successful recovery requires development of a set of positive coping skills (being able to identify "triggers," organize one's day and disengage from negative situations); as well as strong social and family supports. This is difficult for many offenders because of weakened family ties, and long-standing psychosocial problems, which put them at greater risk for relapse by virtue of their extreme socioeconomic deficits, exposure to drug-using associates, and other high-risk situations

The benefits of engaging the faith community in both prevention and treatment of substance abuse and dependence cannot be overstated, as the spiritual model of addiction is one of the most influential in America (Galanter, 2007). Twelve-Step fellowships - Alcoholics Anonymous (AA), Narcotics Anonymous (NA), etc., and 12-Step program models emphasize the importance of a spiritual path to recovery; recognizing a Higher Power (God) beyond one's self, and a desire to achieve health through a connection with that which transcends the individual. Many churches actively support spiritual recovery models by opening their facilities for meetings, maintaining lists of available community resources, and/or operating transitional housing programs.

Healthy, productive ex-offenders can fortify families and resurrect the fragile communities that receive them socially, politically and economically. These same men and women also bring with them overwhelming potential public health and safety challenges, if their permission has been granted for this version to appear in e-Publications@Marquette. SAGE Publications does not grant permission for this article to be further copied/distributed or hosted elsewhere without the express permission from SAGE Publications. 
communities and governmental agencies do not provide them with appropriate, compassionate care. Faith-based organizations have a significant role to play in reintegrating residents returning from prison. Communities that receive these residents are depending on faithbased organizations to respond to fill the void that the state has been unwilling or unable to address. Nationwide, prison officials are encouraging community and faith-based organizations to assist them in developing plans to deal with the more systemic problems, such as substance abuse, lack of educational/vocational skills and housing. Local public safety officials are relying on the faith community to help keep large numbers of offenders out of the revolving door between incarceration and freedom. However, faith-based organizations cannot continue to respond effectively without an expansion of true partnership opportunities and public investment in building their capacity to provide services.

\section{Discussion and Policy Implications}

With unprecedented numbers of formerly incarcerated men and women expected to be released from the nation's prisons, corrections officials sought innovative ways to increase the chance that fewer of them will return. Many officials turned to faith and character-based programs aimed at rehabilitation as well as reintegration that seek to change inmates' internal motivations as well as external behaviors. The Bush Administration strongly supported such programs, as a key focus of its Faith-Based and Community Initiative, an effort to encourage religious charities and other non-profits to provide social services.

Faith-based prison programs typically include training in such secular topics as "life skills," including reading, managing personal finances, and dealing with family issues. Some programs also aim at character transformation, sometimes with a deeply religious component. And some groups will assist in finding employment, either through job referrals or transportation to job interviews. Among the questions about the programs is whether they are truly effective in their ultimate non-religious goal of reducing recidivism. At this early stage of the programs' development, insufficient research exists to supply a solid answer. And, even if participation in religious permission has been granted for this version to appear in e-Publications@Marquette. SAGE Publications does not grant permission for this article to be further copied/distributed or hosted elsewhere without the express permission from SAGE Publications. 
programming was correlated with reduced recidivism, questions would remain on how to discern whether the reduction was based exclusively on religious participation, the secular benefits that these programs also provide, or a combination thereof. In future analyses of these programs it will be important to try to determine which factors are most important in re-entry success.

And some groups have charged that, even if the programs eventually prove to be effective, they are nonetheless illegal. Critics worried that the programs blur the legal line separating church and state have mounted challenges to the programs' constitutionality in courts around the country. At the heart of the legal disputes is whether the government is merely accommodating prisoners' right to freely practice their faith - a constitutional protection that must be afforded to those under its custody, who do not have usual access to religious services - or actually supporting religious indoctrination, in violation of the law. To operate within the bounds of the Constitution, prison programs must (1) be "neutral," without showing preference to one faith over another, or to religious over secular programming; (2)not mandate participation but allow inmates' to choose voluntarily to attend; and (3)ensure that religious content is not financed with taxpayer money.

Addressing the crisis in corrections requires policy intervention, because the present corrections reform debate is limited largely to "inside the building" discussions between bureaucrats, legislators and traditional public safety interests. The response to reintegration thus far has overwhelmingly been from a program perspective and few community and/or faith-based organizations are in a position to make investments in public policy. This imbalance hinders comprehensive reintegration efforts. Increasing the capacity of community and faithbased organizations to contribute to public policy discussions increases successful reintegration efforts, by adding a unified community voice to the discussions. An additional benefit is that ownership/buy-in of reintegration and public safety outcomes expand. permission has been granted for this version to appear in e-Publications@Marquette. SAGE Publications does not grant permission for this article to be further copied/distributed or hosted elsewhere without the express permission from SAGE Publications. 
NOT THE PUBLISHED VERSION; this is the author's final, peer-reviewed manuscript. The published version may be accessed by following the link in the citation at the bottom of the page.

Based on existing research, we recommend the following:

\section{Developing Evidence-Based Practice}

To support more rigorous testing of faith-based corrections models, policy makers and corrections officials implementing faithbased initiatives need to clearly define the intended outcomes of the initiative, create benchmarks for measuring success, and implement systems for tracking and analyzing outcomes data. To facilitate evaluation, program offerings should be standardized to provide a measurable treatment that is consistent over time and across facilities. When developing programming, secular models that have been shown to be effective should be reviewed and possibly adapted to the faithbased environment.

\section{Leveraging Private Resources}

One of the greatest benefits of faith-based prison programming is that it brings extensive program offerings into facilities at a minimal cost. The primary costs are the expenses for a somewhat expanded chaplaincy team and the additional demands on staff time driven by increased volunteer and inmate activity, although these added demands may be balanced with reductions in behavioral problems among inmates. Local volunteers, particularly from the faith community, are a tremendous untapped resource for both faith-based and traditional prisons and a potential asset for budget-strapped systems.

\section{Extending Success Beyond Release}

Like all corrections programs, faith-based initiatives intended to have a long-term impact need to address the reentry process. While positive outcomes may result inside prisons (e.g., adjustment, less disciplinary issues) there is not much known about "over time" and upon release. There is a need for providing the continuity of support needed to extend program benefits beyond the prison walls. Corrections officials implementing faith-based initiatives should incorporate mechanisms for extending the support and guidance provided by the programming through release and reentry. They permission has been granted for this version to appear in e-Publications@Marquette. SAGE Publications does not grant permission for this article to be further copied/distributed or hosted elsewhere without the express permission from SAGE Publications. 
NOT THE PUBLISHED VERSION; this is the author's final, peer-reviewed manuscript. The published version may be accessed by following the link in the citation at the bottom of the page.

should also ensure that the faith-based and character-development activities are complemented with vocational training and educational opportunities that develop the concrete skills necessary for reentry success.

\section{Avoiding Religious Discrimination}

Faith-based efforts in public correctional facilities can successfully serve inmates from different faiths and avoid religious discrimination. Many of the most popular faith-based corrections programs, such as the InnerChange Freedom Initiative, are exclusively Christian and explicitly religious, and these types of programs have run into legal challenges because of their bias toward a specific creed or denomination and the blurring of lines between church and state (Henriques \& Lehren, 2006). But, there may be ways to design programs to draw on the perceived benefits of a faith-based approach while avoiding some of the church-state conflicts encountered by other faith-based corrections programs. For example, having all faith-based programming provided by volunteers using private funds, including a nonreligious character-development component in the model, making participation voluntary, explicitly avoiding any form of religious test for program participation, and recruiting volunteers from both Christian and non-Christian faiths (La Vigne et al., 2007). Religious diversity could benefit other faith-based corrections initiatives. Specific policy-related issues that should be considered include the following:

\section{Prison Infrastructure:}

1. Correctional institutions should be encouraged, wherever practical, to utilize faith-based programs that address documented criminogenic needs. Evidence-based programming that has been shown to impact the offender's lives should be made available to the faith community.

2. Wardens and Superintendents should be encouraged to develop programs which will facilitate a cultural change in institutions to encourage collaboration with faith-based service providers.

3. Develop a standard training program for staff, volunteers, and the community to facilitate working together at each institution.

Special Needs Offenders in Correctional Institutions, (2012): pg. 319-344. DOI. This article is C SAGE Publications and permission has been granted for this version to appear in e-Publications@Marquette. SAGE Publications does not grant permission for this article to be further copied/distributed or hosted elsewhere without the express permission from SAGE Publications. 
The program should include information on the ethics of working with offenders, confidentiality issues, ensuring the safety and security of volunteers, working with volunteers, and the rules and regulations for volunteers.

4. Improvements should be made in the various Corrections Departments with regard to communication about programs and services between the staff and the volunteers, the staff and the community, and other parts of the criminal justice system and the community.

\section{Institutional Programming:}

1. Departments of Corrections should work with the faith community, and volunteers to develop and expand programs within the institutions such as life skills programs, financial management/budgeting programs, personal hygiene programs, and family programs including classes on parenting.

2. Involve the faith community when appropriate in the development of release plans for the offender that flow from the institution to community reentry.

Reentry Programming:

1. Methods should be developed to increase and encourage the involvement of the community and the faith community in various reentry efforts, and to encourage collaboration among faith groups.

2. Inform offenders of various options before leaving prison or immediately upon release. This could be accomplished through seminars, with free legal or consultation services, along with the increased involvement of the community and faith community.

3. Partner with grassroots and community organizations in an educational effort towards the general public aimed at decreasing the negative stigma of ex-offenders and making the public aware of the needs involved in the process of reentry. permission has been granted for this version to appear in e-Publications@Marquette. SAGE Publications does not grant permission for this article to be further copied/distributed or hosted elsewhere without the express permission from SAGE Publications. 
NOT THE PUBLISHED VERSION; this is the author's final, peer-reviewed manuscript. The published version may be accessed by following the link in the citation at the bottom of the page.

\section{Alternatives to Incarceration:}

1. Revise statutes to increase judicial use of community options for non-violent offenders so that prison space can be reserved for violent offenders.

2. Encourage faith-based programs to supplement existing community and diversionary programs for offenders and provide services that are not currently available.

3. State agencies need to take a more active role in linking with the faith-based community to develop programs to meet the gaps in services to adult and juvenile offenders.

4. Expand partnership efforts to work with the employment centers and faith community to increase practical employment opportunities for offenders in the community. A job placement program should be implemented, focusing on the following: providing information on job fairs to ex-offenders, education of businesses/employers on the benefits of hiring ex-offenders, incentives for employers to hire ex-offenders (i.e. tax breaks), and the increased involvement of faith-based groups/community groups.

\section{Closing Remarks}

More research on these issues is just the starting point. Action is needed to address the multitude of policies and practices that ensnare men and women in systems that are unable to recognize and accommodate their needs as individuals and members of various communities. Men and women leaving prison face so many obstacles that perhaps the spiritual side of prisoners is the missing element in bringing about rehabilitation and/or facilitating successful reintegration upon release from prison. Prison efforts such as education, vocational training and counseling are good, but they fail to target core values. Without this concentration on basic morals, many prisoners will go on to commit other crimes. Faith-based efforts offer spiritual development to inmates by preparing them for a job, teaching how to manage finances, and instilling in them strong values. Moreover, administrators appear to be willing to allow religion-based ministries into prisons. Women and men should be supported - at the individual, family, and community level - in their efforts to attain self-sufficiency and successful lives in their communities. Supporting such a process permission has been granted for this version to appear in e-Publications@Marquette. SAGE Publications does not grant permission for this article to be further copied/distributed or hosted elsewhere without the express permission from SAGE Publications. 
requires understanding how poverty, trauma and victimization (past and present) and bad choices can combine to propel human beings into criminal involvement. Assisting these individuals effectively means providing access to coordinated services that address these multiple issues simultaneously.

\section{Cases:}

Cooper v. Pate, 378 U.S. 546 (1964).

Cruz v. Beto, 405 U.S. 319, 322 (1971).

Fulwood v. Clemmer, 206 F.Supp 370 (1962).

O'Lone v. Shabazz, 107 S.Ct. 2400 (1987).

Turner v. Safley, 482 U.S. 78 (1987).

\section{References}

Austin, J. \& Irwin, J. (2001). It's About Time: America's Imprisonment Binge. Belmont, CA: Wadsworth/Thomson Learning.

Besen, W. (2004, January 20). Florida's faith-based prison is a dangerous idea. Tallahassee Democrat [Electronic version]. Retrieved March 10, 2006, from http://www.tallahassee.com/mld/democrat/news/opinion/ 7747872.htm

Bureau of Justice Statistics (2009). Correctional Populations in the United States, 2009. Available: http://bjs.ojp.usdoj.gov/index.cfm?ty=tp\&tid=11\#pubs

Burnside, J., Loucks, N., Adler, J. \& Rose, G.R. (2005). My Brother's Keeper: Faith-Based Units in Prison. Devon, U.K.: Willan Publishing.

Carroll, L. (1974). Blacks, Hacks and Cons: Race Relations in a Maximum Security Prison. Lexington, MA: Lexington Books.

Clear, T. (1992). Does Involvement in Religion Help Prisoners Adjust to Prison? National Council on Crime and Delinquency

Clear, T. \& Sumter, M. (2002). Prisoners, prison, and religion: Religion and adjustment to prison. Journal of Offender Rehabilitation 35(3):127159.

Clear, T. R., Stout, B.D., Dammer, H.R., Kelly, L. Hardyman, P.L. \& Shapiro, C. (1992) Does Involvement in Religion Help Prisoners Adjust to Prison? U.S. Department of Justice: National Institute of Justice.

Clemmer, D. (1958). The Prison Community. New York: Holt, Rinehart and Winston.

Drowns, R. W., \& Hess, K. M. (1995). Juvenile Justice (2nd ed.). St. Paul, MN: West.

Fernander, A., Wilson, J.F., Staton, M. \& Leukefled, C. (2005). Exploring the type-of-crime hypothesis, religiosity, and spirituality in an adult male

Special Needs Offenders in Correctional Institutions, (2012): pg. 319-344. DOI. This article is C SAGE Publications and permission has been granted for this version to appear in e-Publications@Marquette. SAGE Publications does not grant permission for this article to be further copied/distributed or hosted elsewhere without the express permission from SAGE Publications. 
NOT THE PUBLISHED VERSION; this is the author's final, peer-reviewed manuscript. The published version may be accessed by following the link in the citation at the bottom of the page.

prison population. International Journal of Offender Therapy and Comparative Criminology 49:682-695.

Fox, J. G. (1982). Organizational and Racial Conflict in Maximum Security Prisons. Lexington, MA: Lexington Books

Frink, C. (2004, May 7). Breaking into prison [Electronic version]. Christianity Today. Retrieved March 10, 2006, from http://www.txcorrections.org/article.pdf

Galanter, M. (2007). Spirituality and recovery in 12-step programs: An empirical model. Journal of Substance Abuse Treatment 33:265-272.

Hall, S.T. (2003). Faith-based cognitive programs in corrections. Corrections Today 65 (7):108-113,120,137.

Henriques, D. B. \& Lehren. A. (2006, December 10). Religion for a captive audience, paid for by taxes. The New York Times.

Hughes, C. (2006). Potential for widespread fallout in ruling against Iowa faith-based prison program. [Online] Available: http://www.religionandsocialpolicy.org/news/article.cfm?id=4384.

Irwin, J. (1980). Prisons In Turmoil. Boston: Little, Brown.

Johnson, B. R. (2002). Assessing the impact of religious programming and prison industry on recidivism: An exploratory study. Retrieved March 10, 2006, from http://web.archive.org/web/20030408001536/ http://www.txcorrections.org/article.pdf

Johnson, B.R., Larson, D.B, \& Pitts, T.C. (1997) Religious programs, Institutional adjustment, and recidivism among former inmates in prison fellowship programs. Justice Quarterly 14(1): 145-166.

Johnston, N. (1994). Eastern State Penitentiary: Crucible of Good Intentions. Philadelphia: Philadelphia Museum of Art.

Johnston, G. \& Van Ness, D. (2006). Handbook of Restorative Justice. Devon, U.K.: Willan Publishing.

Jones, R.S. \& Schmid, T.J. (2000) Doing Time: Prison Experience and Identity. Stamford, CT: Jai Press.

Jones, R. (2006) Coping With Re-entry: The Role of Prison Fellowship in the Re-entry Process. Paper presented at the annual meetings of the American Society of Criminology, Los Angeles, CA.

Kerley, K., Matthews, T. \& Blanchard, T. (2005). Religiosity, religious participation, and negative prison behaviors. Journal for the Scientific Study of Religion 44, 443-457.

La Vigne, N., Brazzell, D. \& Small, K. (2007). Evaluation of Florida's faith- and character-based institutions. Washington, DC: The Urban Institute.

Maruna, S. (2001). Making Good: How Ex-Convicts Reform and Rebuild Their Lives. Washington, DC: American Psychological Association.

Mears, D.P. (2007). Faith-based reentry programs: Cause for concern or showing promise? Corrections Today 69 (2): 30-33.

Special Needs Offenders in Correctional Institutions, (2012): pg. 319-344. DOI. This article is C SAGE Publications and permission has been granted for this version to appear in e-Publications@Marquette. SAGE Publications does not grant permission for this article to be further copied/distributed or hosted elsewhere without the express permission from SAGE Publications. 
NOT THE PUBLISHED VERSION; this is the author's final, peer-reviewed manuscript. The published version may be

accessed by following the link in the citation at the bottom of the page.

Nolan, P. (2002) Prison Fellowship and Faith-Based initiatives. On the Line: $A$ Publication of the American Correctional Association 25 (5): 1-2.

O'Connor, T.P (2004). What Works, Religion as a Correctional Intervention: Part I. Journal of Community Corrections 14:11-22, 27.

------ (2004-2005). What Works, Religion as a Correctional Intervention: Part II. Journal of Community Corrections 14:4-6, 20-26.

O'Connor, T. and N. Pallone (2002) Religion, The Community, and the Rehabilitation of Criminal Offenders. Binghamton, NY: Haworth Press. (co-published in Journal of Offender Rehabilitation 35 (1,2). 2002.

O'Connor, T.P. \& Perreyclear, M. (2002). Prison religion and its influence on offender rehabilitation. Journal of Offender Rehabilitation 35: 11-33.

Oppenheimer, J.E., Flannelly, K.J. \& Weaver, A.J. (2004). A comparative analysis of the psychological literature on collaboration between clergy and mental-health professionals - perspectives from secular and religious journals: 1970-1999. Pastoral Psychology 53(2):153-162.

Petersilia, J. (2003) When Prisoners Come Home: Parole and Prisoner Reentry. NY: Oxford University Press.

Pew (2008). Pew report finds more than one in 100 adults are behind bars. [Online]. Available:

http://www.pewcenteronthestates.org/news_room_detail.aspx?id=359 12.

Richards, S.C. \& Jones, R.S. (2004) Beating the Perceptual Incarceration Machine: Overcoming Structural Impediments to Reentry, pp. 201-232 in S. Maruna and R. Immarigeon (eds.), After Crime and Punishment: Pathways to offender reintegration. Devon, UK: Willan Publishing.

Rioux, Pual (2007). A Chance For A Fresh Start. Times Picayune. January 28. Sumter, M.T. (2000) Religiousness and Post-Release Community Adjustment, Graduate Research Fellowship-Final Report. U.S. Department of Justice, National Institute of Justice.

Sumter, M.T. \& Clear, T. (2005). Religion in the Correctional Setting. In R. Muraskin (Ed.), Key Correctional Issues (pp. 86-113). Upper Saddle River, NJ: Pearson/Prentice Hall.

Sykes, G. M. (1958). The Society of Captives. Princeton, NJ: Princeton University Press.

Thomas, J. \& Zaitzow, B.H. (2006). Conning or conversion? The role of religion in prison coping. The Prison Journal 86:242-259.

United States Catholic Bishops (2000). Responsibility, rehabilitation, and restoration: A catholic perspective on crime and criminal justice. Washington, D.C.: Office of Social Development \& World Peace: 1-33.

Zaitzow, B.H. (2006). Doing Time: Finding One's Calling and Sharing a Message of Hope. Paper presented at the annual meetings of the American Society of Criminology, Los Angeles, CA.

Special Needs Offenders in Correctional Institutions, (2012): pg. 319-344. DOI. This article is C SAGE Publications and permission has been granted for this version to appear in e-Publications@Marquette. SAGE Publications does not grant permission for this article to be further copied/distributed or hosted elsewhere without the express permission from SAGE Publications. 
NOT THE PUBLISHED VERSION; this is the author's final, peer-reviewed manuscript. The published version may be accessed by following the link in the citation at the bottom of the page.

(1999). Doing time: Everybody's doing it. Criminal Justice Policy

Review, 9, 13-42.

\section{Discussion Questions}

1. What role should outside religious organizations play in corrections (prisons, jails, community corrections)? Should constitutional concerns about separation of church and state factor into this decision?

2. Critics complain that inmates may be coerced into religious programming in order to receive special benefits afforded to program participants. Is this concern relevant, and how should it be addressed by prison administration?

3. Proponents of religious programming in prison claim that their programs work in reducing recidivism. Is it religious programming that is producing the change (transformation/conversion), or is it the additional benefits that produce the change in recidivism rates?

4. An interesting aspect of many of the faith-based groups entering prison to work with prisoners is that for once, the prison has opened its doors to outsiders. This, of course, can reveal some of the negative aspects of prison life that prisons have worked hard to keep from the general public. Do you think that prisons should partner with other, outside social groups to expand its programmatic offering? If so, what concerns might this raise for prison officials?

5. Identify the factors that influence inmates' willingness to participate in religious activities. Discuss the immediate and latent (dys)functions associated with such participation for inmates and staff.

6. What prison religious/spiritual programs have the most potential to promote long-lasting individual change? Are such programs compatible with institutional policies and procedures?

7. Identify future research questions and methods of studying the role of religion and spirituality with incarcerated populations. permission has been granted for this version to appear in e-Publications@Marquette. SAGE Publications does not grant permission for this article to be further copied/distributed or hosted elsewhere without the express permission from SAGE Publications. 
NOT THE PUBLISHED VERSION; this is the author's final, peer-reviewed manuscript. The published version may be accessed by following the link in the citation at the bottom of the page.

\section{Recommended Readings:}

Dammer, H. (1992) Piety in Prison: An Ethnography of Religion in the Correctional Environment. Ann Arbor, MI: University Microfilms International.

Maruna, S., Wilson, L. \& Curran, K. (2006). Why god is often found behind bars: Prison conversions and the crisis of self-narrative. Research in Human Development 3(2\&3):161-184.

Mears, D.P. (2007). Faith-based reentry programs: Cause for concern or showing promise? Corrections Today. American Correctional Association.

Philips, J. \& Coles, R. (2008). Letters from the Dhamma Brothers: Meditation Behind Bars. Pariyatti Publishing.

Sullivan, W.F. (2009). Prison Religion: Faith-Based Reform and the Constitution. Princeton, NJ: University Press, Princeton. 